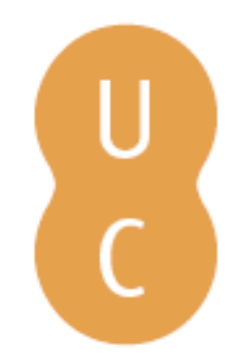

\title{
pommalina
}

\section{El barroco (ultra) peninsular}
Autor(es):
R. de la Flor, Fernando
Publicado por: Imprensa da Universidade de Coimbra; Ediciones Universidad
URL persistente:
URI:http://hdl.handle.net/10316.2/31501
DOI:
DOl:http://dx.doi.org/10.14195/978-989-26-0245-5_1
Accessed : $\quad$ 26-Apr-2023 10:12:38

A navegação consulta e descarregamento dos títulos inseridos nas Bibliotecas Digitais UC Digitalis, UC Pombalina e UC Impactum, pressupõem a aceitação plena e sem reservas dos Termos e Condições de Uso destas Bibliotecas Digitais, disponíveis em https://digitalis.uc.pt/pt-pt/termos.

Conforme exposto nos referidos Termos e Condições de Uso, o descarregamento de títulos de acesso restrito requer uma licença válida de autorização devendo o utilizador aceder ao(s) documento(s) a partir de um endereço de IP da instituição detentora da supramencionada licença.

Ao utilizador é apenas permitido o descarregamento para uso pessoal, pelo que o emprego do(s) título(s) descarregado(s) para outro fim, designadamente comercial, carece de autorização do respetivo autor ou editor da obra.

Na medida em que todas as obras da UC Digitalis se encontram protegidas pelo Código do Direito de Autor e Direitos Conexos e demais legislação aplicável, toda a cópia, parcial ou total, deste documento, nos casos em que é legalmente admitida, deverá conter ou fazer-se acompanhar por este aviso. 
Marta Teixeira Anacleto

Sara Augusto

Zulmira Santos

Coordenação

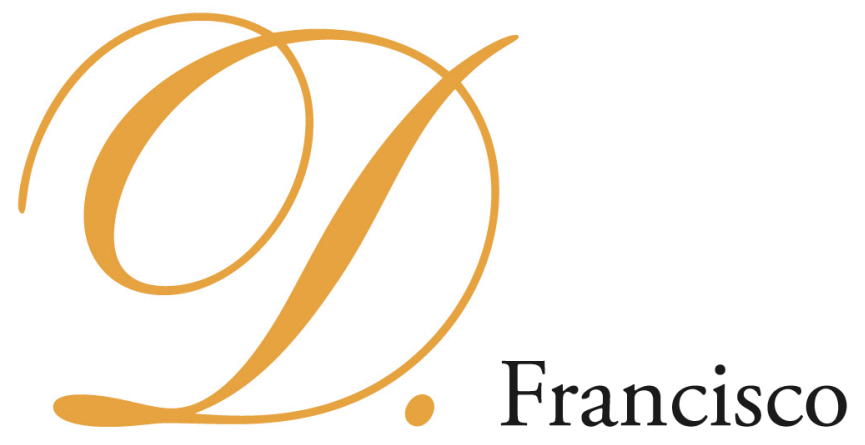

Manuel de Melo e o

Barroco Peninsular 


\title{
EDIĈ̣̃O
}

Imprensa da Universidade de Coimbra Ediciones Universidad Salamanca

\section{COORDENAÇÃo EDITORIAL}

Imprensa da Universidade de Coimbra

URL: http://www.uc.pt/imprensa_uc

Vendas online: http://www.livrariadaimprensa.com

\section{CONCEPÇÃO GRÁFICA}

António Barros

\section{REVISÃO TEXTO}

Sara Augusto

\author{
Pré-Impressão, Impressão e ACABamento \\ www.artipol.net
}

\section{IS B N}

978-989-26-0044-4 (Portugal)

978-84-7800-194-1 (Espanha)

DEPósito LEGAL

$311680 / 10$

OBRA PUBlicada COM O APOIO DE:

FCT Fundação para a Ciência e a Tecnologia

MINISTÉRIO DA CIÊNCIA, TECNOLOCIA E ENSINO SUPERIOR Portugal

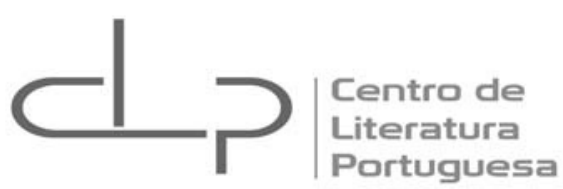

A presente publicação insere-se no Grupo "Poéticas" (coordenação de Marta Teixeira Anacleto) do Centro de Literatura Portuguesa, Unidade de I\&D financiada pela Fundação para a Ciência e a Tecnologia, ao abrigo do Programa Operacional Ciência e Inovação 2010.

(C) Agosto 2010

IMPRENSA DA UNIVERSIDADE DE COIMBRA

EDICIONES UNIVERSIDAD DE SALAMANCA 
Marta Teixeira Anacleto

Sara Augusto

Zulmira Santos

Coordenação

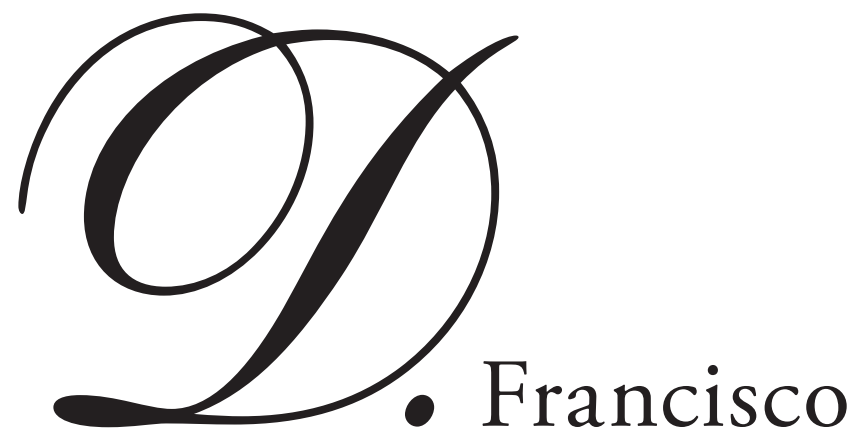

Manuel de Melo e o Barroco Peninsular

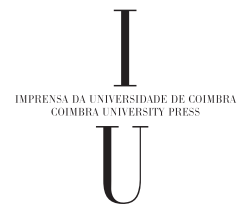


PARTE I

FORMAS E IMAGINÁRIO(s) DO BARROCO 


\section{EL BARROCO (ULTRA) PENINSULAR}

\section{0 .}

La obra plural, mestiza, diversa, transterrada, diafórica y hasta dialógica de Francisco Manuel de Melo, en efecto, puede entenderse como un catálogo ideal de contenidos que habitan el imaginario barroco peninsular, y que entroncan con el inconsciente social de aquel tiempo, y del cual promueven su expresión en distintos géneros.

La vocación y la ambición de significar y de significarse que tuvo este verdadero "centauro ibérico», le condujo a ser un moralista, un politólogo, un satírico, todo lo cual vincula en su personalidad lo que son los rasgos fuertes de una época preocupada por el destino y conformación que recibe el Estado; por el desarrollo en él de una vida civil; por lo que es también la articulación del sujeto en esa vida de la república a través de la negociación y de la «conversación», y, finalmente, expresa la fascinación y tentación de leer el mundo bajo claves personales mantenidas en lo secreto de una biografía. Lo que en el caso de Francisco de Melo significa que a menudo desemboca en una mirada en la que no se excluye el disparate y el humor.

Se conocen muy bien las dificultades inherentes a la descripción de un imaginario, así que me será, sin duda, perdonado que en el preámbulo de este volumen altamente especializado, sin todavía entrar en el núcleo de los problemas concretos de la práctica discursiva del autor convoca (cosa que harán los destacados especialistas aquí reunidos), ofrezca yo una visión muy general (incluso demasiado general y abstracta) de lo que creo que la época pone en juego simultáneamente en las dos culturas y espacios políticos que ocupan la Península. Lo descrito debería conformar por lo menos en alguna medida la peculiaridad de lo que ha constituido lo ibérico. Es preciso atender a definir la singular travesía hecha por la historia por este constructo ibérico, hasta ofrecer en ella el espectáculo de un modelo propio y único de sociedad, de universo cultural y también de talante especial de sus operadores simbólicos. Como justamente sucede con ese tan seńalado Don Francisco de Melo, del que aquí se dará cuenta por extenso.

El dibujo de aquel imaginario que evoco no admite en este breve espacio distinción precisa alguna. Por ejemplo: no será posible introducir matices diferenciadores entre los dos sistemas culturales en que Francisco de Melo se reconoce, y que nosotros reunimos 
aquí, legitimados por el nombre del intelectual que supo operar su sincretismo, y que de sí mismo llegó a decir:

Dos plumas tengo, Oh Fabio, con que escribo.

Hago pues abstracción de situaciones, textos, momentos concretos, incluso de referencias precisas a nuestro autor, para aventurar la idea en sí misma abstracta - y, desde luego, altamente problemática - de un imaginario único generado por una totalidad imperial peninsular ibérica, y cuya cronología se extiende por lo que también, sin demasiada precisión, llamamos «el barroco».

1.

La segunda fase del humanismo hispano, aquella propiamente que se abre a un momento, a una «era barroca», supone el definitivo triunfo de un subtexto que alienta toda la producción cultural del largo tiempo vivido en el Imperio entre la disolución de la clasicidad renacentista y la llegada del nuevo orden ilustrado.

Es la retórica, en cuanto "código de los códigos», la que, en efecto, secretamente domina con su específica lógica ingeniosa y metafórica ${ }^{1}$ todo el plano de la manifestación, determinando su construcción compleja y alentado en su interior la necesidad de mover los afectos y orientar las conductas a unos particulares caminos políticos y religiosos. Funciona en todo momento como el motor que mueve la gran «máquina» de las representaciones, pues, al cabo, lo que la retórica es en verdad es una ciencia del discurso pasional. No se dirige a la ratio sino al pathos.

Toda obra de arte de aquellos tiempos «recios» (al decir de Santa Teresa) comparece en la escena en calidad de objeto o imagen que ha sido finalmente procesada por este verdadero «telescopio aristotélico» (Tesauro ${ }^{2}$ ) de la retórica, el cual tiene como virtud el agrandar y expander las dimensiones materiales, para potenciar en ellas, en primer lugar, los afectos que son capaces de desencadenar, las implicaciones sentimentales (así se agota la «llamada» o apelación de la imagen a confluir con una mirada u horizonte de recepción). Se trata, en todo caso, de llegar a través, en un caso, de los géneros altos hacia la sublimidad, mientras que por la vía de la expresión de lo que es bajo o subordinado se alcanza lo monstruoso y grotesco. Sin olvidar que detrás de esta dimensión "pática», alienta también una poderosa y coherente articulación silogística, además de la reglamentación teológica estricta emanadas del aristotelismo tomista, lo cual legitima tal esfera frente a la ortodoxia. No sólo éste último aristotelismo o "sistema de sistemas» comparece en la obra de arte, sino que, muy a menudo, la imago barroca se ofrece sutilmente también bañada en un clima platónico-hermético, que es el que específica-mente proviene del

\footnotetext{
${ }^{1}$ El papel del ingenio ha sido puesto en evidencia en el mundo hispánico a través particularmente de un discípulo de Grassi, E. Hidalgo-Serna, 1993.

${ }^{2}$ Me refiero aquí expresamente a la gran obra de la retórica barroca, la enciclopedia procedimental de E. Tesauro, 1663.
} 
«trabajo de la palabra» (y el arte que de él depende ${ }^{3}$ ) llevado a cabo por órdenes «seráficas» - carmelitas, franciscanos... -, siempre más versadas en las «historias del cielo» ${ }^{4}$ que en aquellas otras propiamente mundanas.

Se trata de la construcción de un universo difractado entre el «ser» y el "parecer», que es el específico que habita el cristiano, según revela Juan de Orozco en su libro Paradoxas cristianas $^{5}$. Textos como éste ponen de golpe al discurso público del arte y de la literatura frente al escándalo de su enfrentamiento con la razón instrumental, mientras exhibe su fundamento mesiánico de base irracional.

Doble cara pues de la producción discursiva del período que analizamos, en cuanto las tonalidades pasionales, tan ampliamente exhibidas por la pieza barroca, son legitimadas desde el interior del código cultural por una lectura rigurosamente ortodoxa y teológica (vale decir: abstracta) de la realidad del tiempo y del mundo. A esto debemos unir, como componente en verdad esencial, la atmósfera de indefinitud (de suspensión levitatoria) mística, que proviene de la aproximación cristiana al espacio del pensamiento platónico. De modo que, como en su día observara Lacan $^{6}$, en efecto, en la obra de arte barroca nos asomamos al «alma», pero es sólo a través del cuerpo (siempre tenso, siempre expresivo en estos escenarios); vemos la eternidad, pero es por el desgarro producido en el tiempo cotidiano; recibimos una visión del Paraíso, únicamente en cuanto éste se ve metafóricamente encarnado en las cosas de la tierra.

La retórica, en cuanto código de todos los códigos, y cómo instrumento particularmente eficaz a la hora de transmitir una visión ornada y emotiva del caos del mundo y del silencio del ultramundo, domina con sus protocolos el campo de la expresividad nocientífica; es decir, el espacio todo de la producción simbólica. Arte, pues, que tiene por objeto último, no la «realidad» en cuanto tal, sino una versión mitopoética de la misma. Y arte, incluso, que tiene una sobresaliente dimensión hermenéutica, por cuanto apunta a una visión integrada y total del hombre y de su historia. En particular, tal «maquinaria» de construir discursos persuasivos (y aun sublimes) hace posible en condiciones extremas un proceso que podemos vincular a la transubstanciación sacramental. Operación poética y estética, mediante la cual lo real consigue reflectar lo extrarreal y en la configuración de una posible escena sobrenatural se trasmite una verdad del mundo. La gran construcción conceptual de la Eucarístia, propia de este período, y de la que se hicieron garantes y paladines los monarcas hispanos - la pietas austriaca -, transmitiendo con fuerza inusitada su culto al Nuevo Mundo (en cierto modo, el «continente eucarístico»), se convierte para estos reinos en el emblema obsesivo, en el misterium tremens del que la escena del arte ofrece un continuo testimonio, pues no en vano, en él, según la creencia, la metáfora se encarna, se hace real, mostrando el objeto su ser anfibológico, su constitución doble, participando, sí, de lo temporal, pero no menos también aspirando a lo eterno.

\footnotetext{
${ }^{3}$ Mística, plástica y barroco se unen, pues, ello en análisis de tanta influencia como el de E. Orozco, 1977.

${ }^{4}$ V. Stoichita, 1996.

${ }^{5}$ J. de Orozco, 1592.

${ }^{6} \mathrm{~J}$. Lacan, 1973.
} 
El realismo se decanta entre nosotros como el camino ideal para llegar a una suerte de sobrenaturalismo, lo cual disuelve toda polaridad rígida y deja a la cultura hispana en las mejores condiciones para abordar los dos mundos, los dos tiempos ${ }^{7}$, con un claro sentido dilemático, dialéctico. Algo en lo que, al final, podemos suponer se revela maestra la producción de imágenes en el Imperio, precisamente en la época a la que, desde luego no en vano, denominamos por extenso Siglo de Oro.

$\mathrm{Y}$ en efecto, podemos pensar que la tensión metafísica ilumina constantemente los escenarios proyectados, prestándoles a las imagines recibidas de aquella época una tonalidad sobredeterminada. Lo cual impide a cada cosa venir a descansar en su sólo, único, «ser», mientras la fuerza a una aspiración vertiginosa que cada vez se vuelve con más determinación exclusiva hacia lo alto, hacia lo más allá. Plus ultra, en efecto, del mundo, que manifiesta la tensión hacia la absorción de todo lo plural en lo que es uno.

Ambición, o quizá «neurosis», de representar al límite de lo posible (de lo real) que podemos pensar es, también, la sublimación de una específica libido dominandi. Impulso de conquista («espiritual»: Juan de los Ángeles ${ }^{8}$ ), que, sin embargo, habremos de considerar en continua retracción a partir de los momentos históricos que se viven a fines del siglo XVI, y que afecta al proyecto material desenvuelto por un Imperio habituado en el pasado a romper las fronteras de los primitivos órdenes establecidos. Según leemos en la divisa del capitán Vargas Machuca:

\section{A la espada y al compás \\ Más y más, y más y más. ${ }^{9}$}

De este modo paradójico se deshace la polaridad inconciliable que Weber estableció en su día entre las reformas católica y protestante ${ }^{10}$, y los diferentes universos político-sociales que éstas generan. La totalidad imperial hispana no deja de invertir empeños en el campo de lo factual, de lo material, y no pierde nunca enteramente de vista la perspectiva de la necesaria conquista material del mundo, sólo que insufla a esta conquista, y en realidad a esta colonización, el componente imaginario de una trascendencia específica, de una metafisicidad peculiar, internándose en una esfera de acción a la que con justicia se puede denominar "geopolítica». Aquella que será casi completamente negada, por peligrosa y desestructurante, en el campo de las sociedades europeas reformadas.

Aquí la noción de pliegue, de repliegue y drapeado resulta sumamente operativa y visualmente determinante en las imagines de época, por cuanto los ropajes, el tejido lujoso de que se revisten - en la forma específica común de un hábito - los cuerpos barrocos

\footnotetext{
${ }^{7} \mathrm{Y}$ en efecto el enfrentamiento (y acaso también la complementación) entre los dos regímenes temporales, eternidad y finitud, se convierte en un poderoso instrumento para analizar los procesos de vida, como queda en evidencia en la obra de J. E. Nieremberg, 1640.

${ }^{8}$ Fray Juan de los Ángeles, 1595.

${ }^{9}$ B. de Vargas Machuca, 1599.

${ }^{10}$ M. Weber, 1992.
} 
hispanos se constituye en la metáfora perfecta de una «soldadura» - y ya nunca más de una cesura - entre el orden natural y el sobrenatural ${ }^{11}$.

Un específico agon barroco, con componentes bizarros y atrevidos, se extiende sobre la producción del momento altomoderno, y ello en buena medida es debido a esa doble dialéctica abierta por un pensamiento que obstinadamente se da como destino una idealidad metaempírica, fuera de toda razón y atenta por completo a otra lógica, cuyo prestigio extrañamente se mantiene en tal Imperio, más allá incluso de lo que pudiera parecer razonable, y más, desde luego, de lo que aconsejarían las explosivas circunstancias sociopolíticas. Ello gracias, podemos pensar, a la maestría conceptual y discursiva que alcanzan estos artífices; gracias a su señorío efectivo sobre las técnicas de la persuasión y el ornatus que abre en profundidad una via aesthetica, una búsqueda formal de lo que es bello y sublime ${ }^{12}$, y por lo tanto expresa, no la razón, sino la pasión, en cuanto ésta última es la responsable de la verdadera arquitectura de lo humano.

El «delirio» y sus figuraciones quedan así comprometidas en el fondo de la producción imperial hispana, mientras le prestan a la misma gran parte de su especificidad, su marca más característica ${ }^{13}$, componiendo casi la verdadera lingua imperii; la expresión mitopoética del conjunto de idealidades y valores, todos ellos creados bajo un mismo clima religioso y político. El barroco hispano puede ser leído así como el momento fulgurante en que determinadas doctrinas teológico-políticas son procesadas dentro de un complejo sistema retórico-poético, con el objeto de elaborar obras de arte, casi «cultual», que muevan el corazón de una pluralidad de pueblos cuyo imaginario se desea unificar.

2.

Una nueva complejidad se ha instalado, entre tanto, en este mundo hispano, que busca desesperadamente definirse en cuanto singular reino elegido, promoviendo una diferencia altiva, una identidad que, poco a poco, va a pasar de ser pugnaz y ofensiva a adquirir una tonalidad, retractiva, defensiva, melancólica, que caracterizará el «momento barroco». La producción artística transatlántica cobra, creemos, conciencia del peligro de disolución que la construcción teopolítica corre en las tierras de América. Es esta percepción de los "peligros de América» ${ }^{14}$, la que obliga a un plus, a un sobreexceso, a una

\footnotetext{
${ }^{11}$ Sobre este punto, hay que consultar el desarrollo de la metáfora del pliegue en G. Deleuze, 1989. La rigidez hierática que presentan las vestimentas de cortesanos en la pintura virreinal peruana, tal vez deba ser leída aquí como una sutil denuncia de un rompimiento orgullosos del «tapiz» y trama del mundo con el sobremundo, y una deploración del aislamiento soberbio de las élites de poder, que, al cabo no conecta con la materia unificadora en que se inscribe cuanto es sagrado. En todo caso el tejido cobra a nuestros ojos una nueva importancia simbólica, que comienza a ser explorada.

${ }^{12}$ Sobre la sublimidad en las producciones artísticas de nuestro mundo poco se ha dicho. Señalemos por el momento el trabajo de J. L. González García, 2000, acerca de José de Ribera, un pintor de tanta influencia en el orbe andino.

${ }^{13}$ Es preciso señalar que el concepto de «delirio» es trasunto del de «fantasía». Para la reivindicación de esta capacidad en el contexto de la Edad Moderna, debe ahora leerse el libro de E. Grassi, 2003, donde se instituye la capacidad sońadora y relacionadora del hombre como la gran vía de conocimiento abierta por el Humanismo, y previa en todo caso a la revolución del método científico.

${ }^{14}$ Para citar aquí al gran emblemista A. Ferrer de Valdecebro, 1650.
} 
descarga emocional y empática más alta y, por decirlo así, más bizarra, más llena de tonalidad pasional, que se derrama en discursos plurales ${ }^{15}$.

De una búsqueda de la gloria fundamentada en buena medida en la violencia, se pasa imperceptiblemente a la esfera aparatosa de la sicología de la ascesis, de la tensión interiorizada que convierte al alma en un «teatro» de renuncias espectaculares y luchas extremadas y agonistas, para conquistar una particular virtus cristiana que extiende su autoridad ejemplarista por América ${ }^{16}$. En buena medida, la representación plástica y figural se convierte en el instrumento para la inspección y el registro de esta alma humana, ahora tensada por sobrecargas pasionales. El inventario minucioso de los estadios por los que atraviesa la construcción moral del sujeto moderno, que entretanto ha perdido su serenidad y contención clásica, es un objetivo declarado por este arte que se constituye en un saber sobre el nuevo hombre complejo. Homo interior, que va a ser anatomizado, sirviéndose para ello de un instrumento maestro para la época que analizamos: la fisiognomía ${ }^{17}$, el renovado saber que escruta el alma a través de las formas plásticas de los rostros y las expresiones ${ }^{18}$.

De lo heroico-aristocrático, a partir de las fechas que se abocan a la crisis epistémica de fines del XVI, se pasa a una mentalidad dominantemente regida por lo sacrificialascético $^{19}$; ésta también dotada de un acentuado carácter espectacular y volcada hacia la mirada pública, a través de una teatralización impresiva, de la que no dejan de participar las ceremonias de Estado, frecuentemente dedicadas a las efemérides luctuosas.

El arte del momento en buena medida se ocupa de este cambio que afecta grandemente al imaginario, y que convierte a muchas de sus figuras en imágenes que transitan entre dos mundos polares; uno que declina, el aristocrático señorial con sus virtudes específicas, y otro que comienza a emerger titubeante, pues en él se expresan dos vectores contradictorios: los que tratan de integrar de modo dificultoso a los sujetos en esferas y comunidades políticas establecidas, y los que promueven la desconfianza y el desasimiento de toda expresión en y de lo mundano.

El imaginario acomete pues la primera de las grandes fracturas que conoce el momento barroco, esta vez en dos órdenes o lógicas, que, para resumir, podemos denominar el régimen heroico y el régimen depresivo y solipsista en el que se debaten no ya los héroes (en retroceso) sino los santos (en ascenso) ${ }^{20}$.

\footnotetext{
${ }^{15}$ Puede que, como quieren analistas como E. Subirats, 1994, el continente depredado se revele en cuanto materialmente vacío (o vaciado), pero no así, desde luego, en el plano de lo simbólico, donde una verdadera operación de resemantización se pone en marcha; la colonización más eficaz resulta ser así «la del imaginario» (S. Gruzinski, 1995); lo que podríamos llamar con A. Prosperi, 1976, la «conquista espiritual».

${ }^{16}$ De la que ha dado cuenta P. Schmit, 1997.

${ }^{17}$ Dos libros, dos fuentes dan cuenta de esto: E. Pujasol, 1637 y A. de Castro, 1676.

${ }^{18}$ El campo de la fisiognomía en la Edad Moderna fue abordado en su día por J. Caro Baroja, 1988.

${ }^{19}$ Para definir los valores que animan el primer momento (la fase heroico-aristocrática), determinada por el «medro», y de la que no nos ocupamos, véase A. Alvarez-Ossorio, 2001.

${ }^{20}$ El cierto componente depresivo de la santidad barroca ha sido analizado a propósito del ejemplo que ofrece San Juan de la Cruz, por J. Álvarez, 1997.
} 
En terminología del filósofo barroco por excelencia, Spinoza ${ }^{21}$, cierta producción adquiere una tonalidad exaltante, potenciadora de la vida, componedora de mundos sociales en franco proceso de mejora material. Mientras, otra, en la dirección contraria, atiende a descomponer las libidos fundantes y a ofrecer una visión catastrófica de la historia acaecida, a punto de clausurarse en su «undécima hora», dando por prácticamente finalizada la historia del hombre sobre la tierra, al tiempo que anuncia mesiánicamente la «tercera venida» de Cristo a la tierra ${ }^{22}$.

Esta última es la línea, creemos, que termina por imponer su «lógica» en los espacios de representación hispanos, siempre movidos por una necesidad ejemplarizante y catequizadora. En consecuencia, los objetos emblemáticos de las funciones de dirección de los asuntos del mundo yacen pues a menudo arrojados a los pies de los héroes-víctimas, en una suerte de vanitas de todopoderosa presencia en estos escenarios. Mientras, la ética y la estética de la renuncia se modulan en el siglo siguiendo el modelo bíblico de un Job, también siempre presente cuando se trata de la representación de un catolicismo, el cual elige autorepresentarse en cuanto victimario, y ello antes que como real verdugo de pueblos e idiosincrasias innúmeras ${ }^{23}$. El «fantasma» de una culpa nacional se interioriza en el modo de un pecado privado. Son los cuerpos particulares, con sus sacrificios y oblaciones, quienes purgan las transgresiones cometidas por el régimen político y económico que los representa. Una «mentalidad martirial» se impone por doquier, en efecto, repletando con su «teatralización» impresiva la escena del arte.

En razón de este fantasma de culpa irredimible, la interpretación negativa, milenarista, de la historia material del Imperio se impone progresivamente, desde finales del siglo XVI, en medio de un ambiente de general tribulación ${ }^{24}$, mientras, íntimamente asociado a ello, crece el sentimiento fideista de dejar a Dios la dirección final de aquello hacia lo que el transcurso de la historia aboca ${ }^{25}$. El reino (sońado) de Dios deviene, en palabras de un historiador, exclusivo «arquetipo político» ${ }^{26}$.

Estas ideologías muestran en cierta manera su fundamento crepuscular, pues a las urgencias de las finalidades instrumentales se le superpone siempre un sentimiento preciso del fin disolutivo y concluyente. Cosa que vemos construirse paso a paso a través del

\footnotetext{
${ }^{21}$ Del que ahora puede verse un excelente ensayo en D. Tatián, 2001.

22 Como hará M. Lacunza y Díaz, 1977.

${ }^{23}$ La presencia de un "complejo de Job» en la cultura hispana es indubitable, así como la huella de patetismo religioso que imprime a las representaciones del dolor. Señalemos aquí un comentario al Libro de Job, que conoció múltiples ediciones en el Barroco, el de Juan de Pineda, 1601.

${ }^{24}$ Tribulación. He aquí un concepto importante para el momento. Tribulación de los sujetos, pero, también, y más importante, tribulación de los pueblos, en particular del pueblo elegido, algo que podemos definir con la fórmula condensada y paradójica de que en realidad "Dios castiga a los que ama». Véase sobre el asunto el gran tratado de P. Ribadeneira, 1988, construido para explicar la derrota naval de La Invencible.

${ }^{25}$ Este es el horizonte hacia el que apuntan textos teóricos que tuvieron una extensa lectura - y edición - al otro lado del Atlántico. Entre ellos debemos señalar, por la explicitud que manifiesta en su propio título, la obra de Juan de Pineda, 1588.

${ }^{26}$ Cf. M. García Pelayo, 1955.
} 
poderoso instrumento de la palabra homilética ${ }^{27}$, el cual demasiado a menudo se constituye entre los pueblos que utilizan el castellano como un leer y ordenar el mundo (y a sus sujetos) en cuanto encaminados hacia sus postrimerías y novísimos. Memento mori, ciertamente. Sufrimiento mesiánico que se deja leer en la clave ofrecida por Isaías 40, en cuanto futura promesa de constitución de una Jerusalem celestial.

Empero, superando esta propia dialéctica - que en homenaje a las leyes inevitables de la termodinámica moderna podemos denominar entrópica, y, a la postre, catastrófica -, el empuje de unas élites poseedoras todavía de una mentalidad señorial de supremacía y poder requiere el que, aun en medio de los mensajes más articulados a favor de la dejación y la nihilificación de lo humano, termine, con todo, por imponerse una visión mirífica, esplendente, del poder y la jerarquía. Aquella, justamente, que el arte del período no dejará de glosar, sometido como a menudo está, a un régimen de mecenazgo nobiliario.

El derroche, desechando su vulnerabilidad a los ojos de la ética (sobre todo de la ética protestante), y sorteando el rechazo que produce en los temperamentos ascéticos, se pone de lado de la estética. Paradoja desconcertante esta, de la que el oro y los dorados se hacen garantes. La representación enigmática y destellante de éstos en los espacios plásticos virreinales denota una materialidad ahora sublimada. El oro (y su locus: Potosí) fundamenta la trayectoria del imperio elegido; forma parte del diseńo providencialista; «realiza» cristiandad ${ }^{28}$. Campuzano y Sotomayor lo expresa contundentemente cuando en su Planeta católico anima a conquistar nuevas tierras del oro para la Corona:

También es el sujeto de este libro plata y oro, pues son las provincias de los Moxos las más fértiles de aquestos ricos metales. Mas todos serán necesarios para labrar estatuas a V.M. que por largos siglos publiquen la firmeza de su santo zelo. ${ }^{29}$

En perfecto oxímoron o juego de contrarios, que se transmitió muchas veces por la via regia de las imágenes transmetropolitanas, las composiciones que expresa la abyección y la pobreza virtuosa de los santos de la renuncia y de la humillación física, se traman y complementan con una visión mayestática y fulgurante de los símbolos y signos de su riguroso opuesto: el poder. Éste, en definitiva, sumamente venerado en una sociedad que vive profundamente dependiente de los «servicios de vasallaje», en la figura de la gracia real y del «favor» y de la merced nobiliaria ${ }^{30}$, además del patronazgo que ejercen las poderosas órdenes religiosas. El oro, lo dorado, pues, es en metáfora acreditada la verdadera «sangre» que anima el cuerpo del Leviathan cristiano. Es, en suma instrumento de la Providencia, como así termina por imponerlo una línea de pensamiento en los cronistas que va desde García de Toledo, hasta Acosta y Oréé

${ }^{27}$ El papel de la predicación como formalizadora de una interpretación de la historia y de una lectura del mundo natural y cultural, y ello a su vez como medio de formación de masas, ha sido analizado recientemente por M. A. Núńez Beltrán, 2002.

${ }^{28}$ Como ha explicado R. Mújica, 2002.

${ }^{29}$ Campuzano y Sotomayor, 1646, «Al Lector».

${ }^{30}$ Ver J. M. Ińurritegui, 1998.

${ }^{31}$ P. Duviols, 2002. 
Es propio de aquel imperio multipolar, de base continental múltiple y de la textura de aquel momento único, el que estas fases por las que atraviesa el discurso simbólico y estos momentos de lo sociopolítico se vivan localmente a impulsos de las dinámicas regionales, en contra incluso de los propios avatares generales y de los ritmos específicos por los que atraviesa la monarquía universal católica. Una asincronía se impone desde el principio, haciendo fracasar todos los intentos de homogeneización y poniendo de relieve la complejidad radical de tal espacio hispánico, que realiza a su modo la vivencia de un mundo «paradoxal», donde lo contrario se unifica bajo el lema evangelizador y político: Pluribus in unum.

Ello sucede en todo caso en un mundo y en un modo no-homogéneo, pues cada parcialidad territorial, y en realidad cada dominio o espacio cultural, no metropolitano, acaba por reinventar su propio camino y destino, viviendo su momento particular, muchas veces de espaldas a la suerte general de un disconjunto político, del que a pesar de todo no se puede decir de él que haya simplemente pretendido borrar, aniquilar la diferencia (cosa que, en verdad, sólo la Ilustración intentará con su programa homologador). Sino que es más justo observar, por lo que a la expresión artística del barroco hispano se refiere, el que, incrementando fantásticamente el nivel simbólico de los debates, y elevando los aranceles de aquello que pretende legitimarse a sus ojos, obliga a los productores simbólicos y artistas del momento a una sobrepuja ingeniosa para formular en apariencias cada vez más impresivas y novedosas el trío verdad-belleza-ortodoxia dogmática.

Las modulaciones autóctonas, con su poderoso mestizaje simbólico, forman parte legítima de este modelo productivo, en la forma de una variatio permanente, de un sutil proceso metamórfico, según el cual el mensaje de fondo adopta una estrategia de suave acomodación, cuando ingresa en la nueva órbita distinta y distante. Acomodación, reapropiación, contraconquista, obediencia «desencantada»... Finalmente: disimulación de lo autóctono para mejor adaptarse a su dificultada supervivencia. Estos son ahora los nuevos conceptos que se imponen para un análisis que debe dar cuenta en todo caso de un «hecho circulatorio», donde muy pronto se pierde la conciencia de la dirección que adoptan los fluidos, y en donde por todos los lados se generan prácticas de apropiación bajo distintas coberturas y legitimaciones diversas. En los extremos más tensos de esas actitudes, la acomodación y la disimulación merecen una palabra que los rescate como estrategias procedimentales que gobiernan al cabo en las representaciones virreinales.

Pues, en efecto, sucede que allí donde los vectores producen las obras artísticas, se genera también una suerte de desconfianza última en su «sentido» verdadero, contribuyendo decisivamente a crear así el clima de desconfianza y la atmósfera de irrealidad y engaño que, creemos, termina por dominar en los reinos creados ex novo mediante la violencia y la dominación. El arte aquí, creemos firmemente, no revela la estructura de la materialidad virreinal, sino que contribuye definitivamente a velarla u ocultarla, ante lo que es su potencial capacidad de poner en conflicto la acción, por un lado, y la ley moral por otro. Por eso, frente a este aluvión ejemplificador, que emite la esfera del arte, fenómenos reales, como el de la práctica inexistencia de una santidad americana autóctona 
- salvando el caso de Santa Rosa de Lima ${ }^{32}-$, expresan el fracaso final de las sofisticadas técnicas de persuasión empleadas ${ }^{33}$. Plantus indorum, ciertamente, pues el gigantesco trabajo de la legitimación y la unificación simbólica experimenta el fracaso sin apelación en los datos que ofrece lo real.

Considerada en su totalidad, de la esfera del arte creado en aquel momento, bajo la cobertura de una monarquía eclesiástica, que se pretende universal y decidida integradora de sus reinos pluricontinentales, puede asegurarse aquello mismo que los cosmólogos barrocos atribuían a un universo recién descubierto como infinito ${ }^{34}$; es decir, el que en él el centro estaba en todos lados y los límites o circunferencia en ningún punto que pudiera ser localizado ${ }^{35}$. Ello conforma un mundo compuesto (pero sólo en el discurso que lo representa $\left.{ }^{36}\right)$. De él hay que decir que es, sobre todo, un universal simbólico, una semiosfera, entonces: un clima imaginal. Mundo simbólico, como fue conocido a través de Picinelli y su obra central para el despliegue de las metáforas en el Nuevo Mundo ${ }^{37}$; texto que pretende una lectura global en clave mitopoética del universo natural y cultural en que se mueve el hombre, suministrando la clave de su quimérica legibilidad total ${ }^{38}$. Esto compensa lo que por otra parte no se puede controlar ni someter a ley de las manifestaciones de lo real, que se revelan plenas de conflictos y provocadoras de fracturas de la ley moral.

El modelo al que la evolución del discurso cultural del Imperio tiende es, desde luego, a un constructo o "cuerpo" natural cerrado, en el que, sustituyéndose de una vez la vieja concepción anatómica de un corazón que irradia, todo se remite ahora a la imagen más compleja de un sistema circulatorio de nueva planta, precisamente aquel que Harvey describiera en ese gran monumento de la concepción organicista barroca, su Exercitatio anatomica de motu cordis et sanguinis in animalibus, en 1628.

Ello en realidad genera un tan amplio torrente de energía semántica, modulado por idiolectos y formas autóctonas de decir la misma pretendida verdad universal, que aquella al fin se agota; «secándose» al final, y para muchos años, las posibilidades combinatorias, los registros metafóricos y las elasticidades sintácticas y morfológicas de los discursos sobre el mundo que cupiera emanar desde aquella posición singular (y en realidad panóptico, único alzado con la pretensión de visualizar los «dos reinos», el del mundo visible y el del invisible). Señorío de las representaciones; monarquía de las metaforología, que es la que con autoridad detentan los ingenios hispanos del XVII y buena parte del XVIII. Este

\footnotetext{
${ }^{32}$ R. Mújica, 2001.
}

${ }^{33}$ A. Rubial García, 1999.

${ }^{34}$ Para una idea precisa de este universo infinito de la cosmología de la segunda fase de la Era Moderna, véase la obra de G. Bruno, y el análisis que de la misma ha realizado recientemente M.A. Granada, 2000.

${ }^{35}$ Infinita esfera, en efecto, que se convierte en núcleo a su vez de infinitos juegos de lenguaje, y que ha sido revisada en este sentido por K. Harries, 1975.

${ }^{36}$ R. Chartier, 1992.

${ }^{37}$ Sobre la importancia de este texto enciclopédico da cuenta el proyecto editorial del Colegio de Michoacán para la publicación de la traducción de El mundo simbólico iniciada en 1997, con B. Skinfill como editora.

38 Sobre el problema de la legibilidad del mundo que practican las culturas, es ahora preciso leer a $\mathrm{H}$. Blumemberg, 2001. 
exceso de gesto y esta ambición semiótica y neurosis de representar contiene y engendra las semillas de la futura inevitable depresión de los lenguajes artísticos imperiales; cosa acaecida ya en el siglo XIX, en todo el ámbito de la antigua monarquía universal. Tal «ruina» del orden simbólico metaforiza a su vez la estrepitosa disolución del cuerpo material de una república cristiana, que, al fin, decae de su esfuerzo unificador de fragmentos incomponibles, y comienza, incluso, a volverse en contra del orden metafísico que la sustenta ${ }^{39}$.

El emplazamiento virreinal termina mostrando a los ojos de sus agentes el carácter represivo y colonial que desde el primer momento tiene. En estas condiciones, la cobertura de un arte que legitima, ocultándola, la realidad de un continente extractivo, fundamentalmente proveedor, y por lo tanto explotado, se hace progresivamente insostenible, adquiriendo sus manifestaciones el aire intencionalmente arcaico, y casi naif, que tienen, como final estrategia de un discurso vuelto imposible.

La llegada de la racionalidad burguesa marca el fin de régimen para la articulación barroca de la representación, en su versión hispana, y casi sin desmontar ni desconstruir críticamente sus mecanismos relojeros la relega, condenando de antemano a un infierno o purgatorio del que - nos parece - el Barroco, el barroco vivido more hispano, todavía no ha acabado verdaderamente de salir ${ }^{40}$.

Este volumen representa en este sentido una posibilidad más de devolver a la producción que estudia aquel carácter arquitectónico, integral e integrado, majestuoso, que de hecho tuvo; la profunda fidelidad a los principios que expresa. Esto último bajo dos aspectos centrales: uno, en la forma de una antropología general del más allá - el «otro absoluto» -, y, en paralelo, con el esfuerzo de integración de todo lo disímil y distante para constituir con él un improbable cuerpo «biopolítico», una sola comunidad, un solo organismo; imperio, por lo demás, figuralmente parecido a aquel mítico fundador de la monarquía hispana: Gerión, el monstruo que integra en sí los cuerpos de sus hermanos, obrando al unísono con ellos.

Estas mismas representaciones tributan también su homenaje a la construcción específica del sujeto moderno, tal y como hoy todavía lo conocemos, junto también a la de un Estado que por primera vez en la historia se dotó de complejos mecanismos para el desarrollo y afianzamiento de una "cultura de la obediencia», que, a través de una suerte de primitiva "sociedad del espectáculo» ${ }^{41}$, opera como política atenta antes a lograr la persuasión por la via aesthetica y por la palabra, que por lo que es la pura sujeción y el despotismo absoluto.

\footnotetext{
${ }^{39}$ Pues, en efecto, es propio del Barroco encontrar en el lenguaje la semilla de la corrupción final de la esfera teológica y de todo el principio de su verosimilitud, tan brillantemente construida como violentamente desconstruida. Véase esta posibilidad desarrollada por M. Cesareo, 1995, a propósito de los predicadores conceptistas de la Colonia.

${ }^{40}$ Para la historia de la reivindicación de un barroco hispano seńalo ahora a quien fuera el primero de sus apologistas, E. D'Ors, 1999. Una de las últimas revisiones generalistas del concepto pueden encontrarse en I. Chiampi, 2000. Cf. también F. R. de la Flor, 2002.

${ }^{41}$ Para este concepto, resulta inevitable el mencionar a G. Debord, 1976. Así como también la idea de un «Estado cultural», desarrollada por el conocedor de la retórica de la Edad Moderna, Marc Fumaroli, 1991. Una reflexión sobre los alcances posmodernos que alcanza el régimen espectacular y festivo secular en la órbita hispana se puede encontrar en F. R. de la Flor, 2003.
} 
Pues ciertamente, podemos pensar que tal arte, el arte que hoy estudiamos o contemplamos, nos persuade estéticamente de aquello que ética o políticamente, en tanto sujetos post-ilustrados, estamos obligados a rechazar. Violenta paradoja ésta ante la que nos pone el Barroco hispanus (como diría D'Ors), cuyo imaginario nos disponemos a abrir someramente para ver el catálogo museístico de sus figuras, donde reside acaso la clave de su peculiar «lectura» del mundo.

3.

El imaginario barroco se escande en una pluralidad de figuras que resulta imposible inventariar, pues en verdad abarcan el total del cosmos en el que el hombre vive configurando su ámbito simbólico. Una peculiaridad, empero, puede adelantarse acerca de este imaginario: el que las energías productivas de símbolos en el período manifiestan una grave tensión hacia la fantasmagoría, hacia el dominio de una illusio colectiva, tratando de asentar una axiología, un sistema de valores trabado y coherente que vertebra al cabo un modelo, una cosmología. La fantasía conduce esta deriva; ella propone sus figuraciones al imaginario y desencadena los procesos todos de la inventio, que se viven con efervescencia en el sistema cultural hispano. De ello se hace garante la representación del iter (del iter extático: Kircher ${ }^{42}$; del peregrinaje del libro y del autor: Pomá de Ayala). Alegoría, pues, nuclear, esta del camino, del movimiento y la protensión hacia el trayecto, y lo que son sus correspondientes figuras: el peregrino, el viajero, el misionero, el náufrago. Podemos decir de todos ellos que su destino es el salirse del mundo, caminar hacia su límite, buscar la muerte y la cesación, que adviene en la forma de una verdad transterrena (después del «sueño» del mundo). Muerte que pone en muchas ocasiones el punto final a la aventura hispana (salida de un mundo entendido en cuanto locura y sinrazón, como bien se ejemplifica en ese sujeto ideal que propone el Quijote), y que significa el umbral oscuro e indeterminado para el paréntesis de la vida humana concebida como el lugar de una prueba, como una verdadera Tabla de Cebes.

Todo lo que ponga en suspenso (o en sospecha) el orden de lo real (sin negarlo), es acogido con vehemencia por una sociedad estatigrafiada, determinada por un complejo de culpa inextinguible que a su vez practica lecturas plurales y dinámicas de lo que se le ofrece.

Instalada en una suerte de delirio visual, y en la desregularización de lo literal que contiene el lenguaje, ello en el fenómeno bien conocido por los historiadores de la literatura del conceptismo y el culteranismo (que debemos también adaptar al terreno del arte), el conjunto de las prácticas artísticas penetran en un espacio metafórico donde la polaridad del referente cede a favor de la parte comparada (de la parte propiamente fantasmal), describiendo el conjunto relacional entonces un arco muy tenso, y recorriendo en realidad una distancia imaginal extrema, que a menudo se propone como unión y

${ }^{42}$ Me refiero a la importante obra de A. Kircher sobre el viaje astral, 1671. 
soldadura del cielo con la tierra. Ya lo dijo Gracián ${ }^{43}$ : el concepto es la relación más quimérica posible que cabe establecer entre dos objetos, cuya conexión se propone a la imaginación del receptor con el objeto de mover sus pasiones (y hacerla avanzar en el conocimiento de una creación al cabo «conceptuosa», producto de un Deus artifex.

El signo jeroglífico, las calidades emblemáticas que adopta tal arte, denuncian en él esa proposición a la lectura aguda, esa entrega a una mirada que sepa o pueda elevarse de sus planos materiales y objetuales hasta las esferas del hacer concepto. Mirar lo barroco es un ejercicio siempre de sinergia, de llevar hacia la imago todo lo que ésta desencadena en la memoria de una comunidades separadas por la naturaleza, y que aun viendo dificultada su fusión por la explotación, se encuentra al cabo unidas por el lazo imaginario de lo teopolítico. Memoria cultural y cultual de unos pueblos profundos ("pueblos teólogos»: Calderón), «linces a los misterios» (de nuevo, Calderón), sumamente entrenados en desvelar el trasfondo mitopoético de las cosas, y a los que los analistas de la modernidad no han hecho gran justicia en lo que propiamente constituye su «mérito». Pues, en efecto, apoyándose en genealogías plurales que se hunden en los territorios de lo mítico, de lo histórico-fabuloso y hasta de lo «titánico», es la verdad que en el imperio hercúleo, en el mundo donde opera Gerión, y donde se reúne por un tiempo la fuerza concentrada de pueblos disímiles, todo alcanza un rasgo tensivo y sobredeterminado, sin que debe excluirse de él el soplo vivificador de la tragedia (pues ésta se cumple una y otra vez en la historia material).

$\mathrm{El}$ arte del barroco hispano, allá donde se encuentre, penetra abiertamente en la órbita difuminada de lo conceptuoso, de lo lingüístico, de lo semántico, que trata de negociar el lazo que termine por construir una identidad planetaria, que al cabo abarque a toda la humanidad, y permita con ello cancelar el deambular por la historia, entendida esta como sucesión de trabajos y de catástrofes, en pos de la reunificación preadámica en el Uno. Esfera simbólico-artística que necesita, por tanto, construir retóricamente su público, y disponerlo jerárquicamente para ser persuadido de lo que allí se representa. Este registro peculiar, en absoluto satisfecho sólo con el dar cuenta de la variedad y belleza del mundo, ni desde luego sumiso a los principios generales de una mera imitatio de la naturaleza en su exclusiva base material, física, se ve por el contrario compelido a dar una explicación hipotética, compleja sobre una tal existencia, forzando los marcos de la representación serena e induciendo un cierto vértigo y clima de sublimidad y de inminente teofanía, la cual, creemos, preside en particular el universo virreinal.

En todos los signos que se ofrecen se percibe una antropología de base cristiana; todo se dispone sobre una base histórica en un movimiento providencialista que, procediendo del Génesis, avanza hacia la parusia.

Lo que se capta es una escena, un «cuadro», un «acto del Universo» en el largo camino de la humanidad en busca de su realización según la Promesa. Es por esta razón que la muerte cobra una presencia desmedida en estos escenarios, pues a nivel del sujeto ésta significa un adelantamiento, y hasta una oportunidad para, saliendo del tiempo concreto y material, ingresar ahora en el tempus maior, configurando en el caso frecuente de la «muerte santa», un momento significativo más que añadir al «archivo», al panteón cris-

\footnotetext{
${ }^{43}$ Ello en la magna obra de la preceptiva retórica barroca, Arte de ingenio. Tratado de la agudeza, 1998.
} 
tiano. A través de una materialidad, siempre cargada de sensualidad y de peso, se vislumbran toda suerte de destellos metafísicos, metaempíricos; visiones desviadas de la «eternidad", de la que habla la metafísica neoescolástica, y con la que especula cierta mística afectiva. Misterios que pretenderán también alcanzarse, no con ciencias experimentales, sino con especulaciones lingüísticas y numerológicas como sucederá con la kabbala de Francisco de Melo, explorada aquí en este volumen por Pedro Serra.

Aquella fantasmagoría que se construye a través de una lógica simbólica presidida por el papel de la analogía ${ }^{44}$ y de la simpatia entis, que autoriza a trazar esquemas de convergencia entre, por ejemplo, la vida de las azucenas y la de la virgen María, tiene precisamente como efecto el sustraer al individuo de la dimensión profana y mecánica del tiempo, algo que reforzado a través del concepto articulador de la fiesta y los frecuentísimos «días geniales y lúdricos», permite una vivencia excepcional de lo político y de lo religioso. La necesidad de edificar memoria ${ }^{45}$ es decisiva en el hacerse de este arte, que lentamente va construyendo el depósito, el museo de una cultura que se siente amenazada por la disolución y cercada de enemigos. De aquí la idea de fasto, la necesidad de marcar un acontecimiento, de dar expresión a un evento, de inmortalizar una circunstancia, entendido todo ello en la forma mayor de un verdadero ejercicio de conmemoración y memoria que funda comunidad (y, de forma especial, comunidad transatlántica).

A medida que se alejan de su núcleo generador, las producciones adquieren nuevos matices que hacen plural y polisémica su lectura, enriqueciendo las periferias territoriales que se convierten en verdaderos centros ${ }^{46}$, a su vez, mostrando su autoridad expresiva mediante la integración de lo autóctono en ellas, que es, precisamente, lo que demanda la dinámica cultural del Imperio.

De este modo, lo recibido se rearticula y se apropia completamente, ańadiéndole al constructo así formado un sentido más universal, más abierto, incluyendo en esta abertura de este modo practicada, la entrada en campo de un fenómeno de matizada negación, de rebeldía disimulada, el cual se ejercita, de nuevo aquí, a través de poderosas figuras de una retórica del comportamiento: la acomodación, la simulación, el silencio; también en lo que son otros modelos de mayor sutileza: la "obediencia desencantada» y la disimulación estratégica, la apropiación según fines particulares de la comunidad subalterna. Efectos todos que planean sobre la producción virreinal, como lectura de «discretos» y no ya «vulgares» ingenios.

Todo ello pasa directamente a la representación de los propios cuerpos, encargados con la misión de figurar lo que constituye la materialidad explosiva del espacio o emplazamiento $^{47}$ virreinal, provocando lo que son sus vivencias excesivas, su relación ansiógena, siempre fracturada entre los signos del pasado autóctono y de la novedad sobrevenida de un mundo otro, el cual imanta las conciencias y las dota de un espesor, de una densidad

\footnotetext{
${ }^{44}$ Sobre este papel de la analogía en la hermenéutica cristiana hay que volver a Foucault, 1968.

${ }^{45}$ Eventualmente, una «memoria artificial», de la que me he ocupado en F. R. Flor, 1996.

${ }^{46} \mathrm{La}$ idea de dobles, triples centros en el régimen imaginario barroco preside la elaboración poética que del período propuso en su día un S. Sarduy, 1974.

${ }^{47}$ Sobre este concepto que expresa muy bien las tensiones que desgarran la difícil convivencia estamental en el seno de la metrópoli transatlántica, véase M. Cesareo, 1995.
} 
semántica nueva, la cual se expresa, naturalmente, en el modo del conflicto, de la paradoja, del oxímoron perfecto.

Lo distante se funde; lo lejano adquiere cercanía constitutiva; de todo lo cual es ejemplo maestro ese traslado sentimental que hacen los ingenios americanos de lo que es el centro de poder representado por los reyes - los reyes distantes ${ }^{48}$-, reinscribiendo sus emblemas en el corazón mismo de las periferias, donde reciben una adhesión no exenta de duplicidad, por cuanto se les conoce como legitimadores de una necesaria (aunque dolorosa) «construcción de la obediencia». Mientras no se renuncia a explorar y tantear los límites que ésta obediencia y subalternidad presenta, y se deslizan cargas críticas y reivindicativas, autoadjudicándose, por parte de los intelectuales virreinales, como hace Pomá de Ayala, una comprensión más recta de lo que es la construcción de la polis cristiana, de la "Ciudad de Dios» ${ }^{49}$, y un superior conocimiento cristiano de todo aquello que apunta a una verdadera gestión de la "política católica».

Los actos imaginarios, la producción simbólica in extenso se cierra sobre sí misma, configurando un clima propio, dentro del cual se vive como en un orbe todavía cerrado por lo que es el concepto precopernicano de una esfera protectiva, de una matriz cósmica que aloja la posibilidad de un planeta, de un mundo que de modo conclusivo se propone como católico. Esto es lo que hace de la periferia un espacio trascendental, y convierte al Perú, en un "pulmón» del sistema imperial, un foco para el siempre ansiado «aumento» de la república cristiana; pues este Perú es, al cabo, el territorio inseguro, nunca enteramente conquistado, subdividido al infinito en minorías políticas inasimilables. De ahí saldrán las orientaciones pictoriales, espaciales que tienden a recrear un espacio común compartido entre el hombre y la divinidad, objeto perseguido una y otra vez por los artistas virreinales, cuyo imaginario está presidido por esta idea misma de la unificación obsesiva de lo disímil, por la armonización de mundos en la realidad descompuestos, o, por mejor decir, incomponibles.

4.

La idea de comunidad política, institucional, permea las manifestaciones, atenta a coagular los peligros de la separación y de la sedición de lo que, debiendo conservarse uno, se encuentra sometido a una amenaza dispersiva siempre latente. La composición de «esferas» donde se encuentra lo igual domina la concepción imaginaria del espacio barroco. Por ello la construcción lenta de la sumisión - de la obediencia - es lo único apto

${ }^{48}$ Cito claramente la acuñación que ha hecho V. Mínguez, 1995, de la peculiar relación que la Corona funda con sus reinos ultramarinos.

${ }^{49}$ Las ciudades virreinales compiten así con la Corte y la metrópoli ejemplar, Madrid, la urbs regia, cuyo dispositivo simbólico y cuya cobertura festiva en cuanto cabeza imperial ha sido ahora analizada por M. J. del Río, 2000. Véase, de carácter más general, A. González Enciso; J. M. Usunáriz Garayoa (eds.), 1999. 
para conjurar el fantasma temible del «golpe de estado ${ }^{50}$, restándole fundamento a la versión hispana de aquel: el alzamiento, la rebelión, la separación de los reinos reunidos.

Los escenógrafos virreinales del poder connotan este con una característica nueva, y que se opone drásticamente al resto de concepciones de dominación occidental. Me refiero a la emergencia del "poder pastoral», del ejercicio de una coerción «dulce», que es expresión de la máxima evangélica: compelere eos intrare ${ }^{51}$. Poder, en todo caso, de hechuras paternalistas, y derivado de la propia nomenclatura jurídica que utiliza la Corona para designar su tutela indiano-occidental: Patronato Real. Ello es determinante para la iconografía del período, que busca siempre representar una enérgica mansuetudo, expresión de una necesidad de integración de todo lo que aparece como separado o en riesgo de perderse. Aquí aparece en toda su dimensión la figura pastoral por excelencia: el obispo. Es decir, la "vara vigilante»" ${ }^{52}$, el «Buen Pastor» ${ }^{53}$, en todo caso, el Príncipe (en su connotación maquiavélica) Eclesiástico, símbolo mismo del nuevo poder, que, ahora, en virtud del ordenamiento cristiano, actúa bajo la compulsión del cuidado y el amor.

Dios y el hombre, afirman estas pinturas y ratifican estas iglesias, comparten el mismo mundo, pero también lo hacen las comunidades de los santos (confundidos e interactuantes siempre a través de los tiempos en el mundo de los vivos), las legiones de los ángeles (y, en otro sentido, también el tropel de los diablos). Finalmente, por su orden, todo se integra en órbitas y esferas poderosas, cuales las de las comunidades religiosas, los estamentos y corporaciones políticas de carácter nacional regional o local, integrando, finalmente, tal dinámica a los propios sujetos, obligados a asumir su posición jerárquica en la «opera coral» del Imperio.

A su vez esa subordinación de las partes a una misma pasión por re-ligare a través de la religio, y la insinuación de que un único espíritu "pneumático» preside el horizonte hacia el que se encamina la comunidad hispánica, es metáfora del mismo sentimiento unificador que orienta la política material de Estado, siempre atenta a lo que manifiesta vínculo, circulación fluida y cerrada, comunicación y soldadura de imaginarios. Ello precipita la disolución de una temida «alteridad» en la gran construcción política de la subalternidad, concepto este que rige la manifestación sociocultural del Virreinato.

Lo unificado en tal jerarquización se ve favorecido por las marcas iconográficas más sutiles: el beso, el entrelazamiento, la mirada amorosa, la designación, la reunión en torno a un solo motivo de acción. Mientras, el fantasma de lo separado, de lo desunido, de lo solo, de lo no amorosamente enlazado con lo otro, es crudamente deplorado. Cristo, el que une, se posiciona de este modo frente a Judas y, con él, frente a todo lo que separa, fractura, descompone. A todo también, y sobre todo, lo que se rebela políticamente y se

\footnotetext{
${ }^{50}$ Sobre esta figura cumbre del ordenamiento político altomoderno, es preciso consultar la fuente coetánea, el gran libro de Naude, 1639, y como introito al mismo, naturalmente también el prefacio de L. Marin, 1988.

${ }^{51}$ Sobre esta dialéctica nueva que emerge en el Barroco, y que enfrenta la actuación de la ley profana a la que se ejerce en última instancia en el nombre de Dios, véase A. Serrano Gonzalez, 1987.

${ }^{52}$ A. Ferrer de Valdecebro, 1659.

53 F. Núñez de Cepeda, 1682.
} 
alza contra lo común admitido; gran fantasma este, el de la traición y sedición política, que imanta los cerebros de la época.

Esto último es el signo fatal en que se inscribe la representación demoníaca, visualizando al tiempo la división en el propio seno de lo divino, y la causa misma por lo que se precipita la caída del hombre en la historia: el mito de la expulsión, la condena a la fragmentación y el rompimiento de toda unidad. Los réprobos, las ánimas condenadas aparecen sobre todo como separadas de la esfera de lo divino.

Hay una topología precisa que el barroco construye: está lo alto y lo bajo; la derecha y la izquierda. Esta parcialización, junto también a los colores y su simbólica precisa, son los primeros ejes de lectura que lo arquitectónico y pictorial barroco demandan de las comunidades a que se dirigen y, finalmente, de nosotros, sus distantes analistas. Las escogidas figuraciones maestras, las cuales rigen la superior coherencia que manifiesta esta sociedad multipolar así formada, dan, en buena medida, la espalda a los hechos - a la lectura literal -, interpretándolos desde un prioritario sentido dramático-providencialista, que de todos modos siempre tienen.

Los cuerpos de la totalidad imperial hispana son casi siempre sorprendidos en actos que los sitúan fuera de la conflictiva historia material, mientras los anuncian casi como formando parte de un coro extraterreno, disponiéndose en órbitas concéntricas para dar testimonio ante el Creador. Como así sucede en los monumentales «epílogos» o árboles genealógicos que abundan en el virreinato del Perú y en Brasil. Las lecturas providencialistas que se hacen por entonces de la historia, la piensan en cuanto esfuerzo gigantesco de reunión y síntesis absoluta de la peripecia cristiana en su travesía por las edades. Un núcleo poderoso de doctrina ramifica su mensaje en la forma arborescente que termina por construir una mónada casi leibniziana, un mundo autónomo y cerrado, pendiente sólo de la intervención final que clausura dicha escena, y manifiesta de modo universal el poder, hasta entonces aplazado, de lo numinoso y salvífico.

La historia tiene al cabo un sentido, que se manifiesta en algún lugar fuera de ella. Es por esta razón que el cielo tiene tanta presencia en el diseńo espacial de la pintura barroca hispana, y concretamente en aquella que procede del virreinato del Perú. La fortuna o la voluntad humana se pliegan en los lienzos ante la aparición revelada de la Providencia, la cual supone una ilustración a la observación que hace Gracián:

Es la Providencia suma autora de los Imperios, que no la ciega vulgar Fortuna, ella los forma, y los deshaze, los levanta y los humilla por sus secretos, y altísimos fines ${ }^{54}$.

Los sucesos taumatúrgicos, siempre mediados por los hombres de la santidad, suponen episodios proféticos, confirmaciones temporales en que se contiene lo eterno, en cuanto futura promesa de disolución segura del reino de lo histórico y de lo natural. Son vectores de esperanza ad oculos, refuerzos y recordatorios permanentes de la promesa mesiánica, los que en los territorios de la pintura expresan la llegada de un principio de luz ultraterrena, que se vive a través de los conocidos procesos de reflectación, refracción y difracción,

\footnotetext{
${ }^{54}$ B. Gracián, 1640.
} 
organizando el campo óptico de la pintura bajo la clave de la «visión». Efectos singularmente pictóricos de una luz mensajera de lo divino, cuando choca, golpea o incide en un objeto que pertenece al mundo bajo, a aquello que está en la órbita de lo sublunar ${ }^{55}$.

De ahí la frecuente rotura del cielo para confiar en los rayos lumínicos un mensaje de sostén venido de lo alto. Es así como el mundo en cuanto leído, resulta ser un verdadero place of disaffection imponiendo a toda representación la idea de una naturaleza doliente de las cosas mundanas, una naturaleza afectada ciertamente por el pecado y la caida, y perpetuamente puesta en espera de su redención final ${ }^{56}$.

Esto configura una óptica que penetra capilarmente la producción, ya sea de poemas, de lienzos o de arquitecturas, marcando de todos modos con un signo grave, melancólico, el momento, sí, especialmente dramático, y dando cauce expresivo a un efectivo "malestar del imperio" ${ }^{57}$. Óptica negativa sobre la cual se construye una cultura metafísicamente determinada como estructura de pérdida, de nostalgia, de angustia inconclusa, que apenas la risa "democritea» podrá disolver, por más que ésta también resuene en los cuatro extremos del Imperio.

La idea de futuro material a conquistar y de franca apertura hacia el progreso de lo social no termina de abrirse paso en el campo de lo artístico, bloqueando el que la perspectiva puede ahora volcarse sobre una interioridad burguesa, como la que en el resto de Occidente se realiza, y respecto al que la pintura holandesa de interior se ha convertido en el emblema ${ }^{58}$. Pues sucede que, en los vastos dominios de una monarquía católica, una estructura de obediencia general se pliega por entonces al saber y a las representaciones del mundo arcaicas, que determinan todo con su ejemplo, y sobre las cuales acaso sólo se puede girar, encontrando a cada paso nuevas y más complejas formaciones discursivas, que muy pronto están ya operando en un absoluto vacío de referencia, de que se harán eco con escándalo los filósofos "exteriores»" ${ }^{59}$. Son estos aquellos que, desde la tradición cartesiana, por lo demás instalada en el método y en el pragmatismo de la observación realista, reducen el trabajo de la metáfora hispana a una mera construcción de «telarañas», de visiones desequilibradas.

${ }^{55}$ El papel del tratamiento de estos efectos lumínicos en ciertas representaciones emblemáticas puede ahora ser analizado en el artículo de C-F. Brunon, 2001.

${ }^{56}$ Esta lectura que el Barroco realiza acerca de una naturaleza "caída», la cual, si pudiera llorar y lamentarse lo haría, lo puso de relieve en su día W. Benjamín, 1990.

${ }^{57}$ Como así titula su ensayo iluminador A. Padgen, 2001.

58 S. Alpers, 1987.

${ }^{59}$ La burla de las construcciones logomáquicas de la cultura hispana por parte de los philosophes es un tema de singular importancia. Ello determina una vivencia aislada, defensiva de la lectura practicada en el mundo por las élites hispanas, que, en buena medida, y salvo importantes excepciones, se sienten aisladas del resto de su contexto europeo. Tamaña desautorización de la vivencia hispana ha sido estudiada por Iriarte, 1945. 
5.

Un efecto de sujeción ortodoxa planea al cabo por sobre esta producción, dedicada fundamentalmente a establecer variaciones en un archivo temático, una y otra vez resemantizado acorde con nuevas circunstancias. De ahí ese sentido de inmovilidad, esa fijeza en lo que son sus claves conceptuales - que es en realidad una defensa cerrada y expresa la conservación del clima simbólico -, que adopta tal arte «senza tempo ${ }^{60} \mathrm{o}$ «arte de lo eterno" ${ }^{61}$. En cierto modo, arte en realidad a-temporal, por poco sometido a modas o innovaciones a lo largo de casi doscientos ańos, y en el que las leyes estilísticas se someten a los preceptos normativos con escrupulosidad temerosa ${ }^{62}$. Cuando aquellas innovaciones se producen son lentísimas y se introducen en dosis homeopáticas, para no romper bruscamente con el canon establecido de lo representable, que entretanto sigue bajo censura y vigilancia estricta. Entonces, un arcabuz puede sustituir a una espada en la mano de un ángel (mostrando el inicio del cambio de régimen de patronazgo monárquico desde Santiago hacia San Miguel); una calavera puede dar un giro extraño para exhibir ahora su lado inusual más oscuro y deshabitado (adoptando entonces la pintura prácticas comunes en la representación de la anatomía médica). Variatio y declinación de casos de lo mismo sustantivo según protocolos retóricos; he ahí, de nuevo expreso, el motor de tal producción artística.

De otro lado, las lógicas de la razón, que son también las del progreso y del cambio, conocen entonces un bloqueo significativo y un cierto desdén y desatención en este mundo así caracterizado. En cierto modo eso sucede porque se le sobreimpone un otro orden, esta vez de carácter simbólico, puramente basado en las disposiciones relacionales de la lengua y en la capacidad del ingenio para resaltar en el mundo precisamente todo aquello que escapa a su pesada materialidad. Así se fundamenta una poderosa capacidad alegorista, una hermenéutica simbólica que deshace la escena «real» del mundo.

Ciertamente, como ha enseńado Durand ${ }^{63}$, los universos imaginarios se mueven con una lentitud desajustada con respecto al progreso material de las sociedades. Las esferas, que envuelven como climas o verdaderos «invernaderos» semiológicos las peripecias de los reinos y sus construcciones ideológicas, se desajustan, los mapas pierden sus correspondencias, y al final del Barroco puede decirse que, metafóricamente, el planeta católico se ha introducido en una órbita "fría», alejada de la propia tierra o suelo de base, perdiendo así toda capacidad de representar lo real, sino es envuelto en un halo parabólico, cada vez más ilusionista.

Por fin, este volcarse en la via aesthetica revela de modo suficiente, en lo que es su maniaca sed de belleza formal, el verdadero déficit de felicidad y progreso mundano uniforme, que está a la base de su mecanismo protensivo. En su fondo pudiera habitar una

\footnotetext{
${ }^{60}$ Cito la obra de F. Zeri, 1957.

${ }^{61}$ Como lo denominó S. Sebastián, 1990.

62 Para ver esta «vigilancia» de la ortodoxia dogmática sobre el corpus pictorial e imaginero, debe verse ahora P. Martínez Burgos, 1990.

${ }^{63}$ G. Durand, 2000.
} 
protesta muda hacia el orden de lo real y hacia el tipo de construcción de lo social. Un escapismo se detecta. Así como también una estrategia sublimadora. Ambas tienen efectos sobresalientes en el campo del arte, que ahora no podemos especificar con más precisión, pero que constituyen también mecanismos bien presentes en Francisco de Melo.

El poder de la ilusión (illusio), que está explícito en este esfuerzo, recubre una realidad que podemos suponer al cabo dolorosa, sobre todo para la mentalidad de los artistas que la diseccionan y la "leen», mientras hace pendant estricto con aquella otra «via ascética» que mueve el interior de los grandes espíritus conformados del siglo. Hay un laxismo y un fatalismo que se expresa en violentos usos del claro-oscuro y de la retórica siempre eficaz del tenebrismo hispano.

El esteticismo que manifiestan los discursos de toda índole -nosotros pensamos ahora en los puramente plásticos, artísticos - vinculan la producción a una suerte de melancolía originaria, que ha podido ser interpretada en estos días como el motor secreto de nuestra cultura $^{64}$. Así el tormento aproxima el éxtasis, mientras el dolor y el desgarro expresan una fidelidad inquebrantable a la vida, en cuanto testimonio y paso inevitable hacia todo lo que la excede y sobrepasa.

6.

La alusión a la melancolía nos pone en disposición de comprender el despliegue peculiar de un «yo» barroco ibérico, tensado al máximo por una cultura que ejerce sobre el mismo una misión ejemplarizante, y que tiene como base la modelación supresiva de las grandes pasiones, junto a un sentimiento generalizado de violenta coerción de todo lo que se presenta como natural y directo. En efecto, Comprime affectus, «reprime la pasión», como rezan los lemas de los emblemas epocales, determinados por una actitud, en esto de lo pasional, también neoestoica ${ }^{65}$.

El despliegue gestual de los cuerpos barrocos en el espacio plástico tiene mucho que ver con esta política de la represión pasional, y se modula en figuraciones altamente sofisticadas y sutiles, que pueden empezar a ser aquí nombradas. Entre ellas la derilición, que es una suerte de abandono y laxitud que evidencia la entrega de la vida a las fuerzas que se supone la exceden.

Pero enseguida, también, la taciturnitas, una cualidad que afecta a los cuerpos en una relación directa con el poder, y que exhibe en ellos un predominio de la contención meditabunda, del deseo de poner una expresa cautela en la noticia del mundo.

Gestos también que, y sobre todo, pueden ser relacionados con la obediencia y la entrega de la persona a la autoridad del otro. Reflejo estos últimos de la estructura de sujeción jerarquizante que organiza casi piramidalmente la sociedad barroca hispana. Oblación y sacrificio tampoco están ausentes en esta verdadera cultura de la entrega al

\footnotetext{
${ }^{64}$ Bartra, 2001.

${ }^{65}$ Séneca, el filósofo terapeuta por excelencia, es el referente arqueológico de esta composición sicológica del sujeto barroco hispano. Sobre su influencia todopoderosa en este ámbito, K. A. Blüher, 1970.
} 
otro (y a «lo otro»). En muchas representaciones, el intercambio desigual adquiere la forma antropológicamente muy arcaica de un potlach. Intercambio descompensado, en donde, en efecto, una llamada, un don es respondido inmediatamente con una entrega mayor, total. Los oferentes, los donantes, incluso los mecenas adoptan estratégicamente la gestualidad vinculada a la oblación, a la entrega, al ofrecimiento. Por todas partes de la gran superficie representativa y del desfile de relatos con valor ejemplarizante, se ofrece la posición de la subalternidad, como rebajamiento específico del propio rango mundano, ello continuamente estimulado por el ejemplo mayúsculo de quien fuera el "príncipe escondido", el propio Cristo, que entierra su poder en la órbita de lo sublunar.

En ocasiones que son muy numerosas, la representación incursiona en el territorio extremo de la abyección, cosa que sucede cuando lo figurado (o, mejor, «el» o «la» figurada) renuncia expresamente a sus rasgos culturales y marcas de clase, y se ofrece en su nuda humanidad, marcada incluso por la astenia, por la debilidad orgánica y por los signos que expresan la cercanía fatal de la muerte ${ }^{66}$.

Esta reflexión sobre la abyección del cuerpo cristiano nos introduce en el imaginario fuerte relacionado con el suplicio y el tormento, en ocasiones a través del estrecho pasaje del autoinflingimiento de dolor, como parte del programa de una cultura del padecimiento. Los escenarios que reflejan esto último son variados, aun cuando en todos ellos se trata de presentar un cuerpo rudamente sometido y coaccionado, incluso en lo que son sus movimientos naturales y volicionales. Cuerpos que se dan la tristeza y el apagamiento libidinal como horizonte, expresando eficazmente una victoria completa sobre Eros.

En ellos lo exhibitorio apenas queda matizado; al contrario, en buena medida se trata de poner en pie un «teatro» del duelo y una melancolía sicológica vinculada a la pérdida de deseo del mundo ${ }^{67}$. En este plano se sitúan las figuras del exceso, en particular los eremitas y los integrantes de las órdenes reformadas en la exigencia y en la ablación de las marcas del deseo humano: rechazo pues de los placeres, combate contra las tentaciones, abominación de la Babel metropolitana.

Ejemplarizadas por lo que son estas regresiones crudas al mandato evangélico, las clases sociales más elevadas pueden entonces componer su imagen para la eternidad, en lo que es una franca alusión a lo efímero de su posición y a la eventualidad de su ser encarnado. Retratos virtuosos, que, de alguna manera, se hacen por ello mismo perdonar su lugar preeminente en lo mundano, su inequívoca pertenencia a un espacio de naturaleza ambigua: la Corte. La disimulación aristocrática alcanza altas cotas. La hipocresía se hace consustancial a la vivencia en los territorios transoceánicos de la Corona, marcados por la división de su paisaje humano.

Por su parte, el desnudo, o la tensión hacia él, asociado desde antiguo a las representaciones que expresan una violencia religiosa o estatal ejercida sobre el sujeto, triunfa ahora para dar el reflejo metafísico del esplendor crepuscular de una carne próxima

${ }^{66}$ Sobre este concepto de «abyección», rebajamiento al grado cero de lo humano y «nuda» vida, véanse las reflexiones de G. Agambaen, 1998.

${ }^{67}$ Sobre este «teatro del duelo», F. R. de la Flor, 2002. 
a su redención ${ }^{68}$. La mirada se deleita en estos paisajes originarios relativos a la culpa, al dolor, a lo victimario, mientras da también salida ambigua al Eros, el cual adopta figuraciones encubiertamente polimorfas, y en todo caso muy alejadas del mundo de los intercambios directos, imposibilitando así una lectura o atribución directa, por lo que acaba sorteando los temibles escollos de la censura inquisitorial. Desde lo bíblico a los momentos coyunturales por los que atraviesa una Iglesia, que siempre debe ofrecer su testimonio de sangre, las composiciones ostentan una sintaxis muy poderosa que compone con efectividad el cuadro martirial de una cultura que parece extraordinariamente preparada para dar cuenta de las variedades del dolor humano (ańadiéndole a este "dolor» una enigmática nota de complacencia).

En estos escenarios que nos aplicamos a definir, a partir incluso de sus claves fisiognómicas, toda muestra de progreso social, toda confianza en la marcha del desarrollo material de la humanidad queda como coagulada y fascinada en una obsesiva absorción en la consideración de la vida y de la naturaleza como de antemano perdida, o eminentemente volcada a una trascendencia y metaempíria. Se trata de estructuras del imaginario entrenadas en detener la marcha del tiempo secular, en hacer que el pasado numinoso no acabe enteramente de pasar, dada su virtud de prefigurar simbólicamente el futuro que se desea; ello según una dinámica específicamente vinculada al profetismo escriturario, para el cual en el principio está contenido el Fin.

El planeta católico de signo ibérico vive en su totalidad regido por una lógica cultural de conservación, y en absoluto por una de progreso. De esta actitud salen, hemos dicho, los aspectos eminentemente conmemorativos que adoptan las representaciones, verdaderos objetos de memoria cultural. De ahí también su regresión al momento originario, al lugar genealógico del Pacto, de la Revelación, de la Encarnación, y, en clave política, su apelación continua al momento inaugural donde se iniciaba la conquista del mundo, cuando se operaba en él la derrota de todo lo que se oponía a la Monarquía "Pontifical» Hispana. Celebraciones de una memoria cultural que sigue fiel a los principios fundadores, y que vuelve una y otra vez sobre su archivo, para extraer de él una ejemplificación de la que se pretende decir que tendrá actualidad y presencia hasta el fin de los siglos.

\section{Bibliografía}

AGAMBAEN, Giorgio - Homo sacer. El poder soberano y la nuda vida. Valencia: Pre-Textos, 1998.

ALPEERS, Slavana - El arte de describir: el arte holandés en el siglo XVII. Madrid: Herman Blume, 1997.

ALVAREZ, Javier - Mistica y depresión: San Juan de la Cruz. Madrid: Trotta, 1997.

ALVAREZ-OSSORIO, Antonio - «El arte de medrar en la Corte: rey, nobleza y código de honor», en F. Chacón Jiménez y J. Hernández Franco (eds.), Familias, poderosos y oligarquías. Murcia: Universidad, 2001, pp. 39-60.

BARTRA, Roger - La cultura de la melancolía. Las enfermedades del alma en la España del Siglo de Oro. Barcelona:

Anagrama, 2001.

BENJAMIN, Walter - El origen del drama barroco alemán. Madrid: Taurus, 1990.

\footnotetext{
${ }^{68}$ Sobre ello, véase H. Kamen, 1990.
} 
BLÜHER, Kart - Séneca en España. Investigaciones sobre la recepción de Séneca en España desde el siglo XIII hasta el siglo XVII. Madrid: Gredos, 1970.

BLUMEMBERG, Hans - La legibilidad del mundo. Barcelona: Paidós, 2002.

BRUNON, Claude - «Réflection, réfraction et diffraction dans les Amoris Divini Emblemata de Vaenius», en P. Choné, Le point de vue de l'emblème. Dijon: Editions Universitaires de Dijon, 2001.

CAMPUZANO Y SOTOMAYOR, Baltasar - Planeta católico sobre el psalmo 18. Madrid: Diego Díez de la Carrera, s.a.

CESAREO, Mario - Cruzados, mártires y beatos. Emplazamientos del cuerpo colonial. Indiana: Purdue University Press, 1995.

—, «Antonio Vieira: deconstrucción de Dios y crisis de la verosimilitud barroca», Hispanófila, 114 (1995), pp. 51-63.

CARO BAROJA, Julio - Historia de la Fisiognomía. El rostro y el carácter. Madrid: Siglo XXI, 1988.

CASTRO, Antonio de - Fisionomía de la virtud y del vicio al natural sin colores. Valladolid, Joseph Rueda, 1676.

CHARTIER, Roger - El mundo como representación. Historia cultural entre práctica y representación. Barcelona: Gedisa, 1992.

CHIAMPI, Irlemar - Barroco y modernidad. México: FCE, 2000.

DEBORD, Guy - La sociedad del espectáculo. Barcelona: Castellote Editor, 1976.

DELEUZE, Gilles - El pliegue. Leibniz y el Barroco. Barcelona: Paidós, 1989.

D'ORS, Eugenio - Lo barroco. Madrid: Tecnos, 1999.

DURAND, Gilbert - Lo imaginario. Barcelona: Ediciones del Bronce, 2000.

DUVIOLS, Pierre - «El oro del Perú jen pro o en contra del Evangelio?», en R. Mújica et alt, Barroco peruano. Lima: Banco de Crédito, 2002, pp. 92-94.

FERRER DE VALDECEBRO, Andrés - Peligros de América y calamidades de la Religión Católica. Puebla de los Ángeles: s.i., 1650.

FOUCAULT, Michel - Las palabras y las cosas. México: Siglo XXI, 1978.

FUMAROLI, Marc, L'Etat culturel. Essai sur une religión moderne. París: Editions de Fallois, 1991.

GARCÍA PELAYO, Manuel, El reino de Dios, arquetipo político. Madrid: Centro Estudios Constitucionales, 1955.

GONZÁLEZ ENCISO, Antonio (ed.), Imagen del rey, imagen de los reinos. Pamplona: Eunsa, 1999.

GONZÁLEZ GARCÍA, José Luis, "Jusepe de Ribera y lo trágico sublime: a propósito del martirio de San Bartolomé y su modeletto (1624)», Goya, 277-8 (2000), pp. 214-225.

GRACIÁN, Baltasar - Arte de ingenio. Tratado de la agudeza. Emilio Blanco (ed.). Madrid: Cátedra, 1998.

—, El político. Zaragoza: Diego Dormer, 1640.

GRANADA, Miguel Ángel - Entre Petrarca y Descartes. El umbral de la modernidad. Barcelona: Herder, 1993.

GRASSI, Ernesto - El poder de la fantasía. Observaciones sobre la historia del pensamiento occidental. Barcelona: Anthropos, 1993.

GRUZINSKI, Serge - La colonización del imaginario. Sociedades indígenas y occidentalización en el México español. Siglos XVI-XVIII. México: FCE, 1995.

HARRIES, Honrad - «The Infinite Sphere: Comments on The History of a Metaphor», en Journal of History of Philosophy, XIII/i (1975), pp. 5-15.

HIDALGO SERNA, Emilio - El pensamiento ingenioso en Baltasar Gracián. Barcelona: Anthropos, 1993.

IÑURRITEGUI, José María - La Gracia y la República: el lenguaje político de la teología católica y el príncipe cristiano de Pedro de Ribadeneyra. Madrid: Universidad Complutense, 1998.

IRIARTE, Jesús - "La filosofía española bajo el chiste volteriano", Razón y Fe, 45 (1945), pp. 57-78.

JUAN DE LOS ÁNGELES - Diálogos de la conquista del espiritual y secreto reino de Dios que según el evangelio está dentro de nosotros mismos. Madrid: Viuda de P. Madrigal, 1595. 
KAMEN, Henry - «Nudité et Contre-Réforme en Espagne», en A. Redondo, Le corps dans la societé espagnole des XVI et XVII siècles. París: Publications de la Sorbonne, 1990, pp. 297-307.

KIRCHER, Athanasius - Iter exstaticum. Herbipoli: Johannis Andreae Endteri, 1671.

LACAN, Jacques - "Del Barroco», en J. A. Miller (ed.), El seminario de Jacques Lacan. Buenos Aires/México/Barcelona: Paidós, 1972-1973.

LACUNZA Y DÍAZ, Manuel - Tercera parte de la venida del Mesías en gloria y majestad. Madrid: Editora Nacional, 1977.

MARIN, Louis - Pour une théorie baroque de l'action politique. París: Éditions de París, 1988.

MARTÍNEZ BURGOS, Palma - Ídolos e imágenes. Valladolid: Universidad, 1990.

MINGUEZ, Víctor - Los reyes distantes. Imágenes del poder en el México virreinal. Castellón: Diputación, 1995.

MÚJICA, Ramón - Rosa limensis. Mistica, politica e iconografía en torno a la patrona de América. Lima: IFEA; FCE; BCRP, 2001.

"Arte e identidad: las raíces culturales del barroco peruano», en R. Mújica et alt, El Barroco peruano. Lima: Banco de Crédito Americano, 2002, pp. 1-59.

NAUDE, Gabriel - Considérations politiques sur les coups d'Ëtat. Roma: s.i., 1639.

NIEREMBERG, Juan Eusebio - De la diferencia entre lo temporal y lo eterno. Crisol de desengaño. Madrid: María de Quiñones, 1640.

NÚÑEZ BELTRÁN, Miguel Ángel - «Predicación e historia. Los sermones como interpretación de los acontecimientos históricos», Criticón, 84-85 (2002), pp. 277-293.

NÚNEEZ DE CEPEDA, Francisco - Empresas sacras. R. García Mahíques (ed.). Madrid: Tuero, 1988.

OROZCO, Juan de - Paradoxas cristianas contra las falsqas opinjones del mundo. Segovia: Marcos de Ortega, 1592.

PADGEN, Anthony - «Escuchar a Heráclides: el malestar en el Imperio, 1619-1812», en R. L. Kagan; G. Parker (eds.), España, Europa y el mundo atlántico. Homenaje a J. H. Elliot. Madrid: Marcial Pons; Junta de Castilla y León, 2001.

PINEDA, Juan de - La monarquía Eclesiástica o historia universal del mundo. Salamanca: Juan Fernández, 1588.

Commentariorum in Iob libri tredecim. Hispali: Colegio de San Hermenegildo, 1601.

PROSPERI, Adriano - "America e Apocalisse. Nota sulla 'conquista spirituale' del Nuovo Mondo", Critica Storica, XIII/ 1 (1976), pp. 1-61.

PUJASOL, Esteban - El Sol solo y para todos sol de la filosofía y anatomía de ingenios, en la qual, mirándose cada uno a un espejo, o un amigo a otro su rostro, podrá venir a colegir su natural complexión y temperamento. Barcelona: Pedro Lacavallería, 1637.

OROZCO, Emilio - Mistica, plástica y Barroco. Madrid: Cupsa Editorial, 1977.

RAMA, Ángel - La ciudad letrada. Hannover: Ediciones del Norte, 1984.

RIBADENEIRA, Pedro - Tratado de la tribulación. J. I. Idígoras (ed.). Madrid: Universidad Pontificia, FUE, 1988.

RÍO, María Jesús del - Madrid, urbs regia. Madrid: Marcial Pons, 2000.

R. DE LA FLOR, Fernando - Teatro de la memoria. Siete ensayos de mnemotecnia española de los siglos XVII y XVIII. Salamanca: Junta de Castilla y León, 1994.

—, «Del Barroco a la Posmodernidad: arqueología de la sociedad del espectáculo», en AAVV, Fiesta, juego y ocio en la Historia. Salamanca: Universidad, 2002, pp. 125-147.

—, "Teatros barrocos de la melancolía y el duelo», en Francisco Calvo Serraller (ed.), Madrid: Galaxia/Museo del Prado, 2002, pp. 261-281.

Barroco. Representación e ideología en el mundo hispánico (1580-1680). Madrid: Cátedra, 2002.

RUBIAl, Antonio - La santidad controvertida. México: FCE, 1990.

SARDUY, Severo - Barroco. Buenos Aires: Editorial Sudamericana, 1974.

SCHMITT, Paul - «Neoestoicismo y disciplinamiento social en Iberoamerica colonial (siglo XVII)», en K. Kohut y

S. Rose (eds.), Pensamiento europeo y cultura colonial. Frankfurt/Madrid: Iberoamericana, 1997, pp. 187-204. 
SEBASTIÁN, Santiago - Barroco Iberoamericano. Mensaje iconográfico. Madrid: Encuentro, 1990.

SERRANO GONZÁLEZ, Antonio - "Poder sub specie legis y poder pastoral”, en R. Máiz (comp.), Discurso, poder, sujeto. Lecturas sobre Michael Foucault. Santiago: Universidad, 1987.

STOICHITA, Víctor - El ojo místico. Pintura y visión religiosa en el Siglo de Oro español. Madrid: Alianza, 1986.

SUBIRATS, Eduardo - El continente vacío. La conquista del Nuevo Mundo y la conciencia moderna. Madrid: Anaya, 1994.

TATIÁN, Diego - La cautela del salvaje. Pasiones y politica en Spinoza. Buenos Aires: Adrián Hidalgo Editora, 2001.

TESAURO, Emmanuel - Il cannochiale aristotélico ossia Idea del'arguta ed ingeniosa elocutione che serve a tutta l'arte oratoria, lapidaria e simbolica. Venecia: 1663.

VARGAS MACHUCA, Bernardo de - Milicia y descripción de las Indias. Madrid: Pedro de Madrigal, 1599.

WEBER, Max - La ética protestante y el espiritu del capitalismo. Barcelona: Península, 1992.

ZERI, Francesco - Pittura e Contrarriforma. Torino: Giulio Einaudi, 1957. 
Série

Documentos

Imprensa da Universidade de Coimbra

Coimbra University Press

2010

- U

C • 